\title{
Media Systems and Genre Conventions in Transition: A German Priamel Booklet from Nuremberg, c. 1490
}

\begin{abstract}
The manuscript Cod. Donaueschingen A III 19 of the Badische Landesbibliothek Karlsruhe is a very thin booklet of six leafs in quarto format. It was written by a professional scribe in Nuremberg around 1490. The booklet is titled Priamel red ('Priamel speech') and contains a collection of gnomic texts in Early New High German. The materiality and content of the manuscript reveal it as a special product of a book market that was increasingly dominated by print and in which handmade books became niche products. The later entries and deletions in the manuscript make it clear that the sexually explicit texts in the collection experienced a distinctive reception and provoked reactions. The deletions of the sexually explicit passages could indicate that the texts were initially created for a specific, presumably purely male, readership, and that this readership was to be expanded.
\end{abstract}

\section{The manuscript Cod. Donaueschingen A III 19 as a material object}

The manuscript Cod. Donaueschingen A III 19 of the Badische Landesbibliothek Karlsruhe is a very thin booklet of six leaves of $18.8 \times 13.7 \mathrm{~cm} .{ }^{1}$ It is made of three sheets of paper without watermarks. ${ }^{2}$ Although its contemporary version contains entries from six different hands, the manuscript was originally made by a single scribe ('hand A'). The outer double leaf of the booklet was originally

1 Digital images of the manuscript are provided by the Badische Landesbibliothek Karlsruhe: <https://nbn-resolving.de/urn:nbn:de:bsz:31-37635>. A detailed description of the manuscript by Nicole Eichenberger is published in Manuscripta Mediaevalia, <manuscripta-mediaevalia.de/ dokumente/html/obj31577229>.

2 The chain lines of the paper run horizontally. The original sheets must have had a size of at least $27.4 \times 37.6 \mathrm{~cm}$ and therefore had most probably chancery format $(32 \times 45 \mathrm{~cm})$. Cf. Needham 1994 and Needham 2017 or use the Needham Calculator, <needhamcalculator.net>, provided by the Schönberg Institute for Manuscript Studies. 
blank except for a title indication 'Priamel red' ('Priamel speech') ${ }^{3}$ on fol. $1^{1}$. This leaf was used as a cover with a title page. The four inner leaves were written by 'hand A' with 19 gnomic poems. The individual texts consist of 4 to 14 rhymed verses and are separated only by blank lines. There are no initials, rubrics, headings or other book decorations. 'Hand A's script is a Bastarda, a cursive late Gothic book script without calligraphic ambition. The writing is clearly legible, but a crossed-out verse on fol. $2^{v}$ (Fig. 1), which was written down twice, and a misplaced word in text no. $4,{ }^{4}$ show that the scribe did not work very carefully.

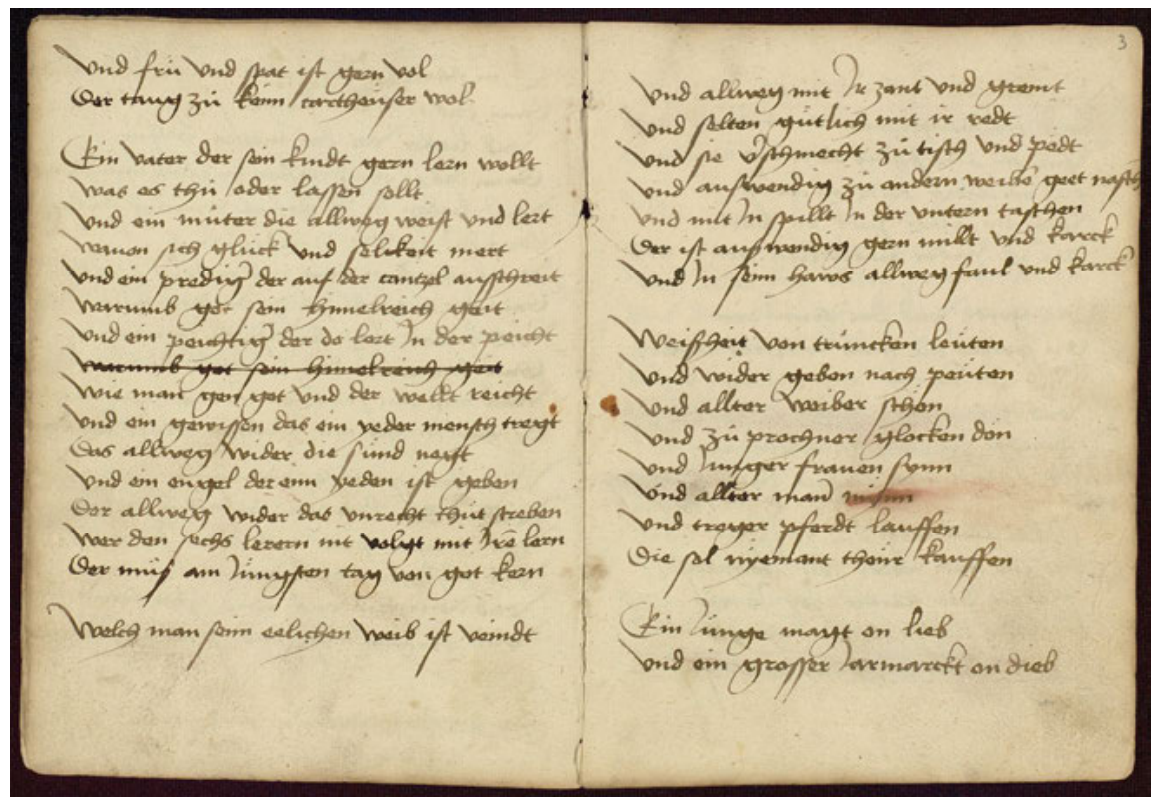

Fig. 1: Karlsruhe, Badische Landesbibliothek, Donaueschingen A III 19, fols $2^{v}-3^{r}$. CC-BY Badische Landesbibliothek.

The booklet was donated in 1868 together with another one (Cod. Donaueschingen A III 20) to the Fürstlich Fürstenbergische Hofbibliothek Donaueschingen

3 All translations in this article are by the author (Marco Heiles). All sites mentioned in this article were last accessed on 24 November 2020.

4 The end of this Priamel reads: der ist außwendig gern milt vnd karck / vnd in seim haus allweg faul vnd karck. The first karck must be emendated to starck. Cf. Kiepe 1984, 77. 
by the Augsburg antiquarian bookseller Albert Fidelis Butsch. The codex Donaueschingen A III 20 was written by the same scribe and has the same format. ${ }^{5}$ It contains a Fastnachtsspiel (carnival play) 'Das Fest des Königs von England' ('The Feast of the King of England') by Hans Rosenplüt (c. 1400-1460). The traces of the old binding show that both booklets were temporarily bound together in one codex. However, these two booklets are not the only ones we know by this scribe. ${ }^{6}$ In the Codex Germ. 13 of the Staats- und Universitätsbibliothek Hamburg, ten of these booklets are bound together, all of which have survived with their covers and title pages. ${ }^{7}$ Two of these title pages even have price indications: iij creutzer (' 3 kreuzer'). ${ }^{8}$ So, these booklets were obviously produced on stock and for sale. They have been preserved only because they were subsequently bound into codices. In three other composite codices, the covers and titlepages were either removed or overwritten. ${ }^{9}$ Altogether 31 booklets are preserved. Those that show watermarks can be dated to $c$. $1472-1490 .^{10}$ All contain texts created in Nuremberg: Priamel, Fastnachtsspiele (carnival plays), Mären (verse narratives) and Minnereden (discursive verse texts on love), mostly by Hans Rosenplüt. Since the manuscripts were also written in a North Bavarian / East Franconian writing idiom, we can assume that they were produced in Nuremberg.

During the active time of our scribe, Nuremberg was one of the largest and economically most important German-speaking cities and a European centre of long distance trade, banking and metal and weapons production. ${ }^{11}$ In the second half of the fifteenth century, its population grew from c. 20,000 (1450) to

5 Digital images: <digital.blb-karlsruhe.de/urn/urn:nbn:de:bsz:31-37656>. Description by Nicole Eichenberger in Manuscripta Mediaevalia <manuscripta-mediaevalia.de/dokumente/html/ obj31577242>.

6 Cf. Simon 1970, 15-17; Kiepe 1984, 176; Horváth and Stork 2002, 122-123.

7 Digital images: <resolver.sub.uni-hamburg.de/kitodo/PPN1665269499>.

8 Hamburg, Staats- und Universitätsbibliothek, Cod. germ. 13, p. 69 and p. 153.

9 Nuremberg, Germanisches Nationalmuseum, Hs. 5339a (c. 1472); Vienna, Nationabibliothek, Cod.13711 (c. 1487/1489); Wolfenbüttel, Herzog August Bibliothek, Cod.18.12 Aug. $4^{\circ}$ (c. 1487/1489). Cf. Kiepe 1984, 175-177.

10 Cf. Kiepe 1984, 175-177. These dates should be checked again. Kiepe's palaeographic dating and his interpretation of the development of the writer's writing as a linear process partly contradicts the watermark dating (as he even remarks himself, Kiepe 1984, 334), which is methodologically more secure and reliable. In the older studies (Simon 1970, 15-17), however, not all watermarks of the manuscripts were accurately identified. With our current resources, this would certainly be possible. On the method cf. Schmitz 2018, 76-83.

11 On Nuremberg in the fifteenth century: Diefenbacher and Beyerstedt 2012; Williams-Krapp 2020, 34-194; Adams and Nichols 2004. 
c. 28,000 inhabitants (1497). ${ }^{12}$ The town was dominated by a small patrician upper class, who obstructed the political participation of the mass of craftsmen and also attempted to control the cultural life of the city. The literacy rate in Nuremberg was high and a broad middle class was able to send its children to German and Latin schools. In the 1470s and 1480s, Nuremberg developed into the most important publishing centre for German prints after Augsburg (Fig. 2). ${ }^{13}$

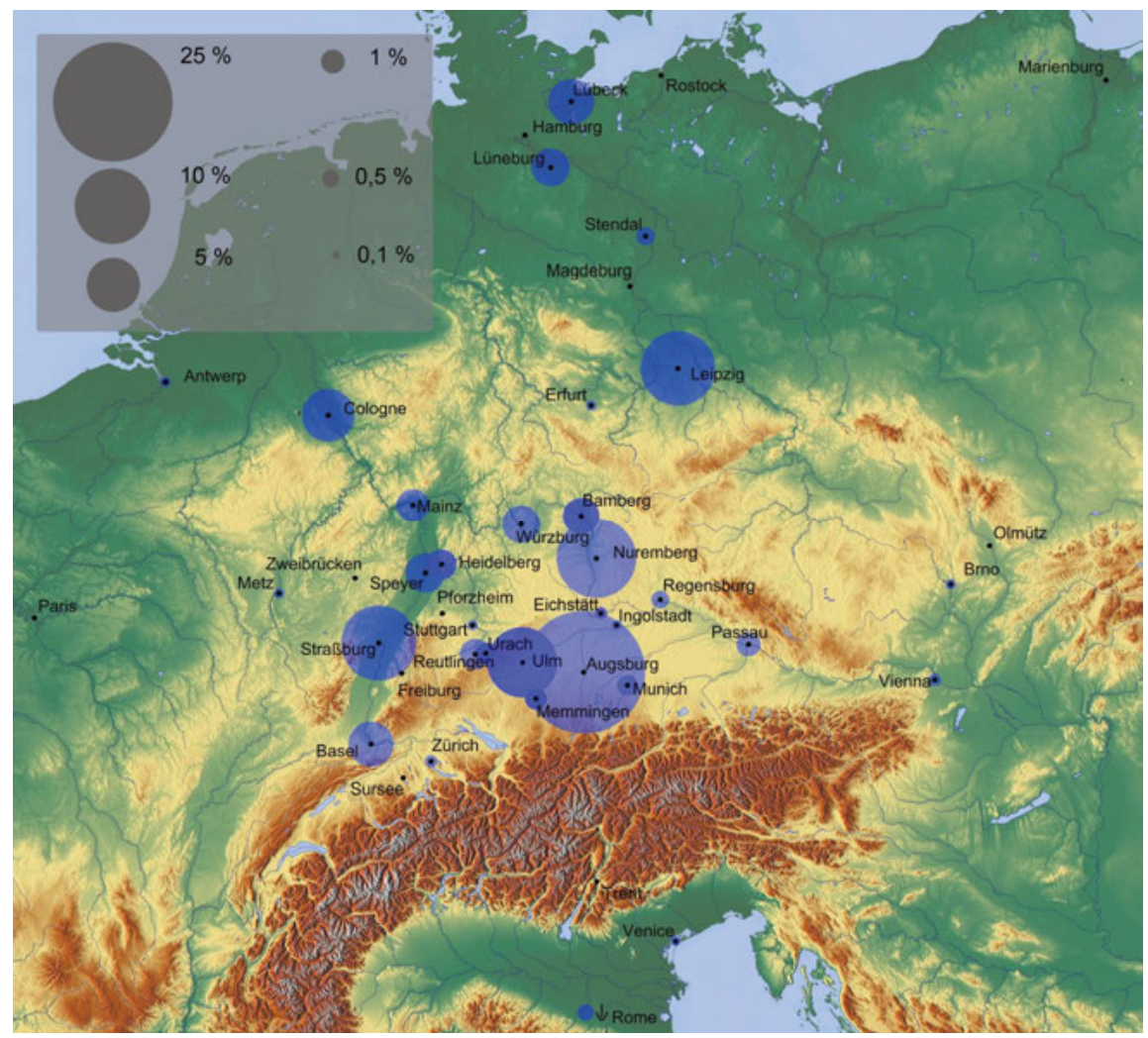

Fig. 2: Production of prints in Germany between 1481 and 1490 per city, number of editions in percent of total production. CC-BY-SA Marco Heiles.

12 Cf. Stadtlexikon Nürnberg, Bevölkerungsentwicklung: http://online-service2.nuernberg.de/ stadtarchiv/objekt_start.fau?prj=verzeichnungen\&dm=Stadtlexikon\&ref=1348.

13 Cf. Heiles, Marco (2011), Topography of German Humanism 1470-1550, https://topographygerman-humanism.artesliteratur.de/Topography\%20of\%20German\%20humanism\%2015501470\%20-\%20maps\%20-\%201.html; Heiles 2010. 
During this period, at least three and up to nine different printing workshops were simultaneously in operation in the city. ${ }^{14}$ In addition, at least two workshops printed xylographic block books in the $1470 s .{ }^{15}$ Apart from Anton Koberger's huge manufactory business specializing in long-distance trade, ${ }^{16}$ the Nuremberg book commerce was characterized by small printing shops that were often active for only a few years. At the same time, the importance of scribes for book production decreased. The registers of new citizens show that the number of new scribes moving to the city rose continuously until c. 1470 , only to fall rapidly in the following three decades. ${ }^{17}$

Compared with other surviving German manuscripts of the late fifteenth century, the manuscript Cod. Donaueschingen A III 19 is an exceptional object for three reasons:

(1) Manuscripts of such brevity (6 leaves) are only very rarely handed down. We must assume that the loss rate of these small unbound booklets was much higher than that of bound codices. According to the figures we know for the survival of fifteenth-century prints, we can expect a loss rate of $99 \%$ or higher. ${ }^{18}$

14 Cf. Typenrepertorium der Wigendrucke: $<$ tw.staatsbibliothek-berlin.de/queries/officequery. xql?place=N\%C3\%BCrnberg $>$; Diefenbach 2003.

15 Hans Sporer and Friedrich Creussner, cf. Merk 2018, 141-144; Kremer 2003.

16 Cf. Bangert 2019, 91-94; Sauer 2017.

17 While 23 scribes became citizens of Nuremberg in the 1460s, there were only 14 in the 1470 s, nine in the 1480s and finally only two in the 1490s. Cf. Kiepe 1984, 149-154 with Table 1.

18 The loss rates of fifteenth-century books cannot be reliably calculated and (due to the contingency of transmission) from the calculated loss rates should not be deduced to the originally existing number of books of individual places, periods or even persons. Information is provided by the known run numbers of individual incunabula prints (European prints with movable type published up to 1500). However, loss rates of incunabula prints vary greatly depending on genre, language and format. For individual editions the values are between $50 \%$ and $100 \%$. The German calendar of Johannes Regiomontanus printed in Nuremberg in 1474 (GW M37472), for example, was printed 1,000 times and only 25 copies have been preserved, which corresponds to a loss rate of $97.5 \%$ (numbers according to Eric White's database of fifteenth-century print runs, <www.cerl.org/resources/incunabula/main\#e_white_researching_ print_runs> and the Gesamtkatalog Wiegendrucke <gesamtkatalogderwiegendrucke.de/docs/ M37472.htm>). Neddermeyer 1996, 27-28 calculates a loss rate of 95\% for the entire incunabula production in Europe and estimates a loss rate of $93 \%$ for European manuscripts of the fifteenth century. For prints of small format (octavo) or with a small number of sheets $(<80$ leaves) he calculates a survival rate of $1,2 \%$ respectively $1,3 \%$, and for vernacular prints of all formats a survival rate of 1,1\% (Neddermeyer 1998, I, 75-78; II, diagram 5). However, Neddermeyer does not even include completely lost print editions in his calculations. Examples for completely lost editions of small format prints are mentioned by Dondi 2020, 587-589. Cf. Trovato 2014, 104-108. 
The fifteenth-century booklets known to us are, with a few exceptions,${ }^{19}$ preserved only because they (like Cod. Donaueschingen A III 19) were at some point bound into a codex and preserved as such by an institution.

(2) Cod. Donaueschingen A III 19 was produced by a professional scribe on stock for the book market and not on behalf of a client. We also know the approximate prize of the booklet. This is a extraordinary setting of manuscript production $^{20}$ in the German-speaking countries of the fifteenth century and there are rarely any known comparable cases. Diebold Lauber's workshop, active in Alsace between c. 1420 and c. 1470, is a prominent exception. The socalled Lauber workshop, however, consisted of many different actors, writers and illuminators, who worked mainly together in the production of large illustrated codices. ${ }^{21}$ While Lauber's handwritten book advertisements also suggest the production of small manuscripts comprising of only one quire, these have not survived. ${ }^{22}$ But, the capital required and the entrepreneurial risk of a cooperative business model for the production and distribution of large codices (be it in manuscript or in print) must have been much higher than in the one-man business of our anonymous scribe. His business model is rather comparable to that of block book printers, whose products are of a similar format (but different in genre), ${ }^{23}$ or that of the Nuremberg craftsman poet Hans Folz, who (in his main profession a barber) self-published his works from 1479 to 1488 with his own typographic printing press with woodcut illustrations. ${ }^{24}$ Folz's prints contain the same text genres as the booklets of the anonymous Nuremberg writer. With their products in the lower price range, both Folz and our writer must have aimed at the same group of buyers. As figures from Venice show, where the transmission situation was much better than in Nuremberg, book prices fell enormously as a result of the spread of letterpress printing in the 1470s and

19 See for example: Berlin, Staatsbibliothek, Hs. 384a-384i (<handschriftencensus.de/3311>) or Nuremberg, Germanisches Nationalmuseum, Historisches Archiv, Bestand Deutsches Reich, Fragen und Antworten über das Freigericht (Wilshörst) 1408/1428 (<ha.gnm.de/ objekt_start.fau?prj=HA-ifaust\&dm=Historisches+Archiv\&ref=31518 $>$ ). These notebooks also only survived as part of a larger collection. Cf. Heiles 2018, 453-455; Schwob 2004, 51.

20 My use of terminology ('setting of manuscript production', 'patterns of visual organisation') is strongly influenced by the Centre for the Study of Manuscript Cultures in Hamburg. See Wimmer et al. 2015.

21 A list of manuscripts is provided by the project 'Diebold Lauber digital': <wirote.informatik. uni-leipzig.de/mediavistik/handschrift/uebersicht>. On Laubers workshop see Fasbender 2012.

22 On Lauber's production of smaller books without illumination see Achnitz 2012.

23 On the genres of blockbook printing see Merk 2018, 15-22.

24 Cf. Klingner 2010, 47-65; Huey 2012, 1-32; Rautenberg 1999. 
continued to fall in the 1480 s and 1490 s. $^{25}$ Smaller prints, such as primers for first-time readers (containing the alphabet, the most important prayers and some psalms), could already be purchased in the 1480s for the equivalent of everyday goods such as 'a chicken, or "an excellent eel”, or a packet of sugar' ${ }^{26}$ The price of three kreuzer (= 12 pfennig), as stated in Hamburg Cod. germ. 13, is also an affordable one. In 1480-1494 Nuremberg, three kreuzer was the prize of 1,5 litres of wine or c. $1,6 \mathrm{~kg}$ beef. ${ }^{27}$ If we compare the prize for one booklet with the daily wages of building craftsmen for 1480-1494, which in summer was two meals and c. 24 pfennig (equivalent to 6 kreuzer), we can see that our scribe had to sell at least three booklets a day to have a comparable income, after subtracting the cost of paper and ink.

(3) The Cod. Donaueschingen A III 19 and the booklets handed down in the Hamburg Cod. germ. 13 make use of a pattern of visual organisation of books whose development is closely connected to the development of early book printing and which we usually know from prints only: the title page. Initially printed books always began on the first page of the first quire, as it was also the case in manuscripts. From the 1470 s onwards, however, printers began to increasingly leave the first page or first folio of the print blank (Fig. 3). ${ }^{28}$ By the end of the 1480s, the pattern of the title page had fully evolved: a page separated from the text contained information for the identification of the text, often supplemented by illustrations and less often by information about the production (printer, place, date). ${ }^{29}$ Of the prints produced in German-speaking countries between 1486 and 1490, 73\% already had a title page, while additional 13.5\% started with one or more blank pages. ${ }^{30}$ The development in Nuremberg, where Hans Folz first printed title pages in 1482, runs parallel to that in Germany as a whole. ${ }^{31}$ The fact that our scribe adapted that new developed pattern of printed books for his manuscript booklets in $c .1490$ shows, how strongly this type of manuscript production was influenced by printing.

25 Cf. Dondi 2020.

26 Dondi 2020, 587.

27 For prizes and wages in Nuremberg see Dirmeier 1984, 212, Table 35.

28 Cf. Rautenberg 2008, 34-38; Rautenberg 2004, 12-14.

29 Rautenberg 2004.

30 Cf. Herz 2008, Fig 1.

31 Cf. Herz 2008. 


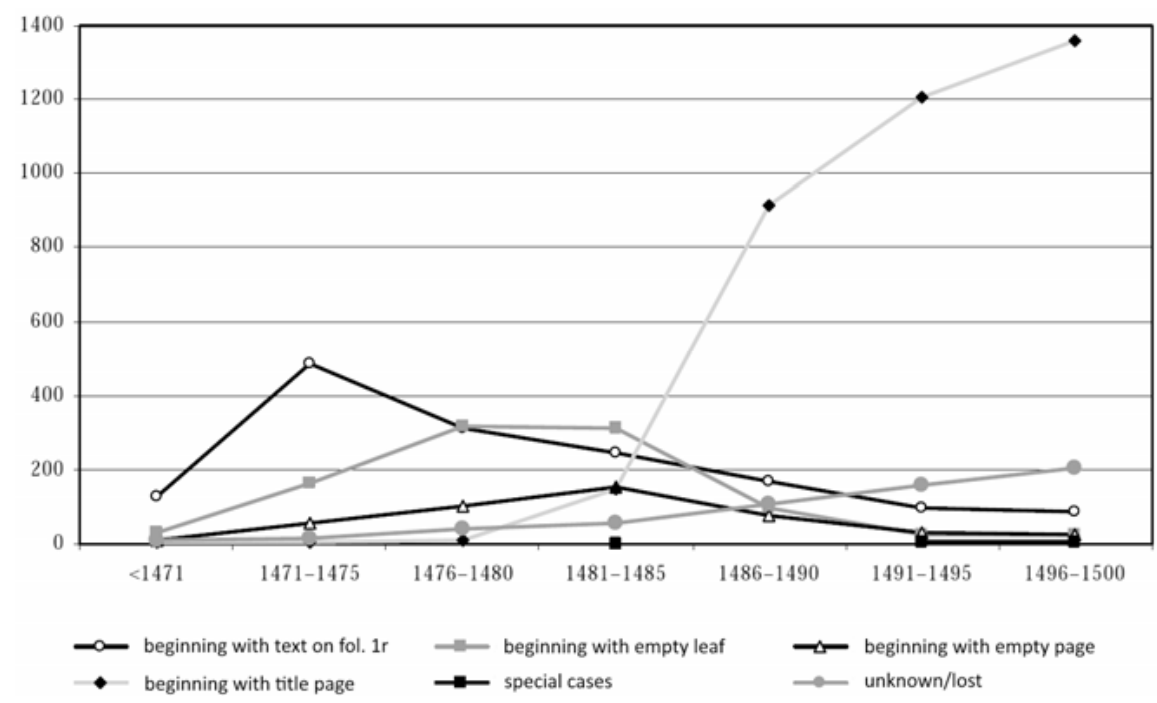

Fig. 3: Patterns of the beginning of books printed in Germany, 1460-1500, total numbers of prints (Source: Rautenberg 2008, Fig. 6). Frau Rautenberg hat der Veröffentlichung in diesem Beitrag (und unter CC BY NC ND) zugestimmt.

\section{Manuscript content and social context}

The Codex Donaueschingen A III 19 belongs to a very rarely transmitted manuscript type of the fifteenth century. It is a single-quire codex with secular popular literature in German and was produced by a professional scribe for the Nuremberg book market, $c .1490$. This scribe produced this kind of unpretentious and undecorated manuscripts on stock. He found himself in competition with typographic printing and its mass production, which influenced both his price design and the layout of the books. However, his products are distinguished from the print production of his time by content and by diversity. Only a fraction of the handwritten preserved Mären, Minnereden, Priamel and carnival plays were printed (or preserved in prints) at all. While Mären were printed in the fifteenth century by at least 13 printers in six cities, ${ }^{32}$ Minnereden are only preserved in six editions before 1500, three of which alone were printed by Hans

32 Cf. Fischer 1983, 241-242. The database Brevitas-Wiki gives a list of 21 Mären printed before 1500: <wiki.brevitas.org/index.php?search $=\mathrm{gw}+\% 2 \mathrm{~B}+\mathrm{M} \% \mathrm{C} 3 \% \mathrm{~A} 4 \mathrm{re} \% 2 \mathrm{FV}$ ersnovelle $>$. The study of the printing tradition of Mären is still a research desideratum. 
Folz in Nuremberg..$^{33}$ Out of the Fastnachstspiele only three are preserved in prints from this time..$^{34}$ All three were composed by Hans Folz, two were also printed by him. The oldest surviving printed collection of Priamel was printed by Johann Schöffer in Mainz as late as $1508 .{ }^{35}$ From the time before, only four or five xylographic single-sheet prints with one or two Priamel or Priamel-like texts preserved (Fig. 4). ${ }^{36}$ This means that the anonymous Nuremberg copyist supplied his customers with literature that did not exist in print and never became popular in printing.

The manuscript Donaueschingen A III 19 is titled 'Priamel red' ('Priamel speech'). ${ }^{37}$ A Priamel is a poem, usually in rhymed couplets, in which different circumstances are described in parallel linked sub-phrases, which in the last concluding part of the poem are connected in such a way that the common ground (tertium comperationis) of the sequence becomes pointedly recognizable. ${ }^{38}$ This structure can easily be detected in an example like text no. 5 in the collection copied by 'hand A' (see Fig. 1):

Weißheit von trüncken leüten
vnd wider geben nach peüten
vnd alter weiber schön
vnd zü prochner glocken dön
vnd junger frauen synn
vnd alter mann mÿnn
vnd treger pferdt lauffen
die sol nüemant theür kauffen.
(Fol. $3^{r}$, no. 5)

The wisdom of drunkards, and the returning after the exchange, and the beauty of old women, and the sound of broken bells, and the intelligence of young women, and the sex of old men, and the running of sluggish horses, should nobody buy dearly.

33 Klingner and Lieb 2013, vol. 2, 149-162; Klingner 2010.

34 Ridder, Przybilski and Schuler 2005, 243.

35 Hierin in disem büchleyn. Findt mañ vil gůter reymen feyn. Manchẽ seltzam gůtẽ schwanck. Lustig zuhoeren bey dem weinßtranck, Mainz: Johann Schöffer, 1508 [VD16 V 1004; USTC 662698]. See Kiepe 1984, 376-378.

36 No.1: Wer sůcht jn eym kvttrolff glas gen $\beta$, Nuremberg?, c. 1460-1470, c. $280 \times 200 \mathrm{~mm}$. Exemplar: Munich, Bayerische Staatsbibliothek, Xylogr. 88. Digital images: <mdz-nbnresolving.de/urn:nbn:de:bvb:12-bsb00083140-5> (see Pfister 1986; Griese 2000, 179). No. 2: Sälig ist der man den sein hand nert, Upper Germany, 1475 (?),256 × 390 mm (see Schreiber 1928, 54, no. 2895; Kiepe 1984, 110, 392, no. 25). No.3: Wer eehalten dinget vmb grossen lon, Nuremberg (?) 1480-1490, $390 \times 283$ mm (see Schreiber 1927, 125, no. 1990; Kiepe 1984, 19-20, Fig. 3, 397, no. ${ }^{\star} 82$ ). No. 4: Dis sein die zehen eygenschafft des alter, Augsburg or Lake Constance 1482, $240 \times 347 \mathrm{~mm}$ (see Schreiber 1927, 57, no. 1881, Kiepe 1984, 405, 423). No. 5: $O$ Mensch bedenckh allzeit dein noth, Nuremberg (?), sixteenth century (?), $280 \times 385 \mathrm{~mm}$ (see Schreiber 1928, 54, no. 2895; Kiepe 1984, 35 and 414).

37 Cod. Donaueschingen A III 19, fol. $1^{\mathrm{r}}$.

38 Cf. Dicke 2007. On the genre characteristic, see Williams-Krapp 2020, 63-66; Gerhardt 2007, 7-30. 
From Middle High German times (c.1150-1350), only Priamel-like quartrains (Priamel-Vierzeiler) are known, especially from Freidank (d. 1233) and in Hugo von Trimberg's Renner (between 1296 and 1313). Longer Priamel-like constructions without rhyme have first been circulating since the beginning of the fifteenth century, inter alia in student's manuscripts. ${ }^{39}$ However, the Priamel did not develop into a genre until the middle of the fifteenth century in Nuremberg. Although the tradition is mainly anonymous, the majority of Priamel and their development are today attributed to Hans Rosenplüt. ${ }^{40}$ The Priamel appeared in diverse media. The Priamel in Cod. Donaueschingen A III 19 obviously present themselves as reading texts. However, the inclusion of Priamel in carnival plays shows that they can also be used as recitation texts..$^{41}$ Further, Priamel are also epigraphically used for house inscriptions, ${ }^{42}$ and the large format and type of script of most xylographic Priamel broadside prints also indicate that they could be presented as wall posters. ${ }^{43}$ The Priamel is, however, as Christoph Gerhard puts it: 'usually literature from existing literature and not a testimony of spontaneous orality'.44

From the 19 texts written by 'hand A' in Cod. Donaueschingen A III 19, 13 follow the Priamel structure described above (nos 1-6, 14-19). According to Kiepe, six of them belong to the oeuvre of Hans Rosenplüt (no. 1-6)..$^{45}$ The other texts in the collection are also characterised by enumerations and sequences, and are therefore Priamel-like. Three of them are orations of the revue-like carnival play Wettstreit in der Liebe ${ }^{46}$ ('Competition of Love') (nos 8, 9, 11), spoken there by different characters. No. 10 could be an otherwise not transmitted variant of the same or a similar play. No. 12 is a Reimpaarspruch, a gnomic poem in four verses. The title of the booklet, 'Priamel speech', tells us that the contemporary concept of Priamel was broader than our modern scholarly definition.

39 The unrhymed Priamel Alder an weyßheit is for example transmitted in the student or academic manuscripts Munich, Bayerische Staatsbibliothek, Clm 671, fol. 117 $7^{\mathrm{v}}$; Munich, Bayerische Staatsbibliothek, Clm 641, fol. $72^{\mathrm{r}}$; and Lübeck, Stadtbibliothek, Ms. hist. $8^{\circ} 1 \mathrm{a}$, fol. $238^{\mathrm{r}}$. See Heiles forthcoming.

40 See Kiepe 1984, 45-53.

41 Cf. Gerhardt 2007, 29.

42 Cf. Hohenbühel-Heufler 1883.

43 Cf. the measurements of the prints nos 2-5 listed above in n. 36. Cf. Griese 2000, 179-184.

44 Gerhardt 2007, 12: '[...] in aller Regel Literatur aus bereits bestehender Literatur [...] und kein Zeugnis einer spontanen Mündlichkeit'. See also Gerhardt 2007, 12-30.

45 Cf. Kiepe 1984, 348-349.

46 Edition in Keller 1853, 132-137 (no. 16). 
Table 1: Texts written by 'hand A'

\begin{tabular}{|c|c|c|c|}
\hline no. 1 & $\begin{array}{l}\text { Ein schreiber, der lieber tanczt vnd } \\
\text { springt }\end{array}$ & Priamel & 12 verses \\
\hline no. 2 & Wer gern spillt vnd vngern gillt & Priamel & 8 verses \\
\hline no. 3 & Ein vater, der sein kindt gern lern wollt & Priamel & 14 verses \\
\hline no. 4 & Welch man seim eelichen weib ist veindt & Priamel & 8 verses \\
\hline no. 5 & Weißheit von trúncken leüten & Priamel & 8 verses \\
\hline no. 6 & Ein jünge magt on lieb & Priamel & 8 verses \\
\hline no. 7 & Die geÿer vnd die hüner arn & Priamel & 6 verses \\
\hline no. 8 & Mein lieb liebt mir so fast & verses from carnival play & 8 verses \\
\hline no. 9 & Mein fraw liebet mir so ser & verses from carnival play & 8 verses \\
\hline no. 10 & Ewer lieb ist meiner nit gleich & verses from carnival play (?) & 8 verses \\
\hline no. 11 & Mein lieb liebet mir für schnecken & verses from carnival play & 4 verses \\
\hline no. 12 & Es ist ein gemeiner sit & Reimpaarspruch & 4 verses \\
\hline no. 13 & Kein grösser narr mag nit werden & $\begin{array}{l}\text { Priamel (with diverging } \\
\text { structur) }\end{array}$ & 10 verses \\
\hline no. 14 & Ein schweigender schüler & Priamel & $\begin{array}{l}6 \text { verses, } \\
\text { no rhyme }\end{array}$ \\
\hline no. 15 & Poßheit vnd grindig pader & Priamel & 4 verses \\
\hline no. 16 & Wenn man ein einfeltigen betreügt & Priamel & 4 verses \\
\hline no. 17 & Wann das ein weiser eins narren spott & Priamel & 4 verses \\
\hline no. 18 & Ein man, dem er vnd güt zú fleüst & Priamel & 4 verses \\
\hline no. 19 & $\begin{array}{l}\text { Wenn ein rë̈cher ein armen } \\
\text { verschmecht }\end{array}$ & Priamel & 4 verses \\
\hline
\end{tabular}

'Hand A' did not write the texts of Cod. Donaueschingen A III 19 down in a random order, but followed a (conscious or unconscious) scheme. This can firstly be seen in the form of the texts (Table 1). The booklet begins with seven elaborate Priamel of 8 to 14 verses, followed by excerpts from the carnival play and ends with five Priamel of 4 verses. But there is also a thematic order. The booklet begins with a Priamel about the behaviour of priest candidates. A list of negative examples tells the reader how a good priest would act:

Ein Schreiber der lieber tanczt vnd springt dann das er in der kirchen singt vnd lieber vor der metzen hoffirt dann das er eim priester zü altar ministrirt vnd lieber in heimlich winckel schlüff
A scribe who would rather dance and hop than sing in the church, and rather flirt with the town whore than serve a priest at the altar, and rather slink in hidden corners 
dann das er gen predig lüff vnd lieber dry tag pulenbrief schrib dann das er ein stünd zü vesper blib vnd lieber auf der gassen schwantzirt dann das er in den püchern stüdirt wann auß eim solchen ein frommer priester würt

so hat in got mit grossem glück angerürt. (Fol. 2r, no. 1) than run to sermon, and rather write love letters for three days than spend one hour at vespers, and rather stroll in the streets than study in books, if such a person becomes a good priest,

then god has touched him with great blessing.

The following texts deal with morally correct and socially compliant behaviour in a similar way. In no. 2 negative habits are listed that prevent one from becoming a good Carthusian monk (der taug zu keim cartheüser wol), ${ }^{47}$ and in no. 3 positive habits are listed that one should consider if one does not want to be rejected by God on Judgment Day. Priamel no. 4 deals with the husband's behaviour towards his wife:
Welch man sein eelich weib ist veindt vnd allweg mit ir zant vnd greint vnd selten gütlich mit ir redt vnd sie verschmecht zü tisch vnd pedt vnd auswendig zu் andern weibern geet nasch[en]
vnd mit in spillt in der vntern taschen der ist außwendig gern milt vnd karck [emendate: stark $^{48}$ ] vnd in seim haus allweg faul vnd karck. (Fols $2^{\mathrm{v}}-3^{\mathrm{r}}$, no. 3 )

\begin{abstract}
The man who is hostile to his wife, and always fights and yells with her, and seldom speaks well with her, and despises her at the table and in bed, and goes nibbling away at other women, and plays with them in the lower pocket, this man likes to be generous and mean [strong] away from home, but is always lazy and mean in his house.
\end{abstract}

Less focused on morality, the following texts warn against foolish behaviour. They foster a mutual understanding of social judgements and communicate everyday knowledge in the form of stereotypes. Priamel no. 5, already quoted above, shows this clearly: drunken people lie, old women are ugly, young women are stupid and old men impotent. No. 6 adds: Young women have lovers, big fairs are full of thieves, Jews are rich, young men are brave, etc. Using examples from the animal world (in old barns there are mice, in old furs there are lice, and old billy goats have beards), these characteristics are given as part of the

47 Cod. Donaueschingen A III 19, fol. $2^{\mathrm{v}}$.

48 Cf. Kiepe 1984, 77. 
natural order (naturlich art). ${ }^{49}$ In this way, the Priamel are expressing an essentialist world view in which one's 'nature' determines one's behaviour.

Whereas couple relationships and love were previously one topic among others, no. 7 now deals with sex, specifically the (naturally determined) sexual lust of women and prostitutes.

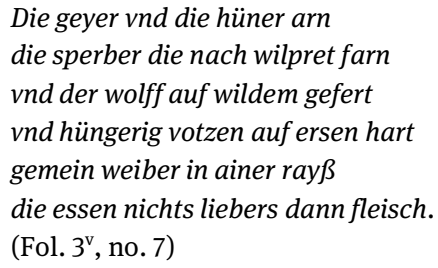

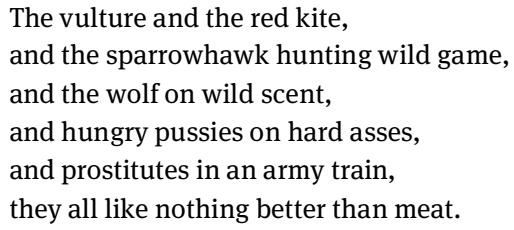

The vulture and the red kite, and the sparrowhawk hunting wild game, and the wolf on wild scent, and hungry pussies on hard asses, and prostitutes in an army train, they all like nothing better than meat.

Thematically, the statements from the Fastnachstspiel follow on from this. These thematise the language of love. The texts parody love confessions by presenting social misconduct (the extreme libido of a woman in no. 8, or the extravagance of a man in no. 9) or by using distorted rhetorical figures (no. 11). A sexual joke (no. 12) ${ }^{50}$ and a Priamel about fools who are so addicted to their wives that they do not notice their adultery (no.13) close this group of texts about love and sexuality.

The last five Priamel give again negative examples of social misconduct. Key words in this section are teufel (devil) and weißheit (wisdom). The devil marks the sin. Human behaviour is judged here in Christian moral categories. The didactic aim of these texts is the avoidance of sin and the attainment of eternal salvation.

\author{
Poßheit vnd grindig pader \\ spiler vnd grosse lieger \\ wucherer vnd geitig pfaffen \\ die sechs hat der teufel beschaffen. \\ (Fol. $5^{r}$, no. 15)
}

Malice and scruffy barbers, gamblers and great liars, usurers and greedy priests, this six were created by the devil.

The wisdom and its counterpart foolishness represent a second, pragmatic value system. The didactic aim here is to avoid stupidity and errors that lead to the loss of social prestige or energy.

49 Cod. Donaueschingen A III 19, fol. $3^{\mathrm{v}}$.

50 Es ist ein gemeiner sit / das der zers vnd der schmidt / Allwegen müsen stan / So sie zủ der arbeit süllen gan 'It is a common custom that the blacksmith and the dick always have to stand while working'. 
Wann das ein weiser eins narren spott vnd ein frommer sich gesellt zü pöser rott wer das den zweien wol an legt derselb kein weißheit in im tregt. (Fol. $5^{v}$, no. 17)

Wenn ein Reycher ein armen verschmecht vnd wenn ein greiff ein mücken vecht vnd wenn ein keyser pöse müntz schlecht die drey haben sich selbs geschwecht. (Fol. 5v , no. 19)
When a wise man mocks fools, and a pious man gets into bad company, he who thinks well of the two carries no wisdom in himself.

When a rich man rejects a poor one, and a griffin catches a gnat, and an emperor strikes bad coins, the three have weakened themselves.

In the collection of Cod. Donaueschingen A III 19, the Priamel is presented as a jocular didactic genre, which takes up discourses on the role of the clergy, on the behaviour of man and woman (especially in couple relationships), and on sin and stupidity. The range of social roles mentioned in the texts reveals that they were written in and for an urban society: peasants and nobles, village life or life at court play no role. The Priamel is instead situated in the city: we encounter scribes (no. 1), priests (no.1, 2, 15), Jews (no. 2, 6), Carthusian monks (no. 2), preachers (no. 3), confessors (no. 3), drinkers (no. 3), prostitutes (no. 7, 14), smiths (no. 12), students (no. 14), judges (no.14), chefs (no. 14), barbers (no. 15), gamblers (no. 15) and usurers (no. 15); the settings are streets (no. 1), churches (no. 1-3) and fairs (no. 5); people read books (no.1) and write love letters (no. 1).

The texts of the Cod. Donaueschingen A III 19 function as a source of selfunderstanding to a middle-class urban audience. They convey a simple morality of conformism and are used to set the readers apart from the lower clergy and the socially marginalised and deviant (gamblers, drinkers and adulterers). The texts are written from a male perspective and also address solely a male audience. Women get devaluated and portrayed as sexually demanding, and permissive, and as objects of male control.

The texts contained in Cod. Donaueschingen A III 19 fit into Werner Williams-Krapp's description of the literature composed in Nuremberg by Hans Rosenplüt and his successors as 'Literatur der Mittelschicht' (middle class literature). Hans Rosenplüt (c. 1400-1460) can indeed be credited as the author of most of the texts in that manuscript. ${ }^{51}$ Rosenpüt's oeuvre is extraordinarily extensive: due to the circumstances of transmission, his authorship is often not

51 On Hans Rosenplüt see Griese 2019; Williams-Krapp 2020, 49-66; Simon 2004; Glier 1992a and 1992b. 
explicitly documented, but at least 25 poems and songs, seven Mären, 140 Priamel and 55 carnival plays can be ascribed to him or his close circle. Rosenplüt acted as a poet only in addition to his daily artisan work, as he was a professional metalworker.

The buyers of the manuscript booklets of the scribe of Cod. Donaueschingen A III 19 can also be assumed to be mainly from the same middle class. However, the circle of buyers and recipients went also beyond the Nuremberg craftsmen. We know for example that Claus Spaun, the first owner of manuscript Wolfenbüttel, Herzog August Bibliothek, Cod. 18.12 Aug. $4^{\circ}$, was a wealthy merchant in Augsburg. ${ }^{52}$

\section{Additions and deletions: the life of Cod. Donaueschingen A III 19}

After 'hand A' produced the Priamel booklet Cod. Donaueschingen A III 19, at least five more persons worked on the manuscript and left traces (see Fig. 5 below). ${ }^{53}$ These can be divided into two basic categories: (1) entries with and (2) entries without a recognizable connection to the rest of the text. Group (1) can be further differentiated into (1.1) additions of entire texts, (1.2) comments, (1.3) repetitions and (1.4) deletions. All entries in this first category indicate that the text of the manuscript has been read and engaged with. They can provide information on the purposes for which the manuscript was used and on the understanding of the texts. The entries in the second category, such as library stamps, page numbers, shelf marks and unconnected texts and notes can also be used to draw conclusions about the history of the object and the milieu and mindset of past owners.

The later entries in the manuscript are more numerous at the beginning and the end of the manuscript. Their chronological order can only be approximated. All additions are palaeographically dated to the first half of the sixteenth century. ${ }^{54}$ The oldest additions are probably those of 'hand E'. These were written on

52 According to Augsburg's tax lists, he was wealthy around 1500, before he became financially impoverished, probably as a result of bankruptcy in 1505. Cf. Fischer 1983, 189-190; Ott 2010.

53 Fig. 5 is available online in full resolution: http://dx.doi.org/10.17613/v6y5-2770 (accessed on 04 December 2020).

54 See the description by Nicole Eichenberger <www.manuscripta-mediaevalia.de/dokumente/ html/obj31577229>. 
fols $2^{\mathrm{r}}$ and $5^{\mathrm{v}}$ on the lower margin and supplement the text of 'hand A' with stylistically and thematically similar texts, short Sprüche of few verses. The first Spruch refers to the topic of the good priest from no. 1 and no. 2.
An dye füeß getretten
Stepping on the feet
ist auch gepetten.
is also praying.

(Fol. 2')

The sexually explicit Sprüche on fol. $5^{\mathrm{v}}$ supplement no. 7, 8 and 12 and convey an equally misogynous image of women as sexual objects.

$\begin{array}{ll}\begin{array}{l}\text { Dorfft der jung vnd mocht der allt } \\ \begin{array}{l}\text { So het kain fraw jrer fúdt gewallt. } \\ \left.\text { (Fol. } 5^{v}\right)\end{array}\end{array} & \begin{array}{l}\text { If the young man was allowed and the old } \\ \text { man could, } \\ \text { no woman would have control over her } \\ \text { vagina. }\end{array} \\ \begin{array}{l}\text { Wer herein get, } \\ \text { vnd jm sein maúl offen stet }\end{array} & \begin{array}{l}\text { Whoever goes in } \\ \text { and has his mouth open, }\end{array} \\ \text { Vnd stoß den czers in di diernen etc. } & \begin{array}{l}\text { should buy pears for a penny } \\ \text { and push the penis into the girl. }\end{array}\end{array}$

'Hand F' comments twice on the last Spruch. Only one of the comments is still readable. It can be understood as affirmation: thue im ('do him').

The entries by 'hand B' on fol. $6^{\mathrm{r}}$, probably made a little later, are also supplements with stylistically similar Sprüche. This is most obvious in the case of the last entry, a Priamel-Vierzeiler: Der teufel vnnd vnglickh
vnnd alter weiber tückh
Reitten offt manichen man
das er nit für sich khomen khan.
(Fol. 6')

\author{
The devil, and misfortune, \\ and the guile of old women \\ often ride many a man \\ so that he cannot make progress.
}

Further entries by 'hand B' are found on fols $1^{\mathrm{r}}$ and $1^{\mathrm{v}}$. The entries on fol. $1^{\mathrm{r}}$ may be probationes pennae. One repeats the title ('Priamel red'), another one breaks off after a few words..$^{55}$ The Spruch on fol. $1^{\mathrm{v}}$ is an antipapistic statement.

Fol. $2^{\mathrm{v}}$ was otherwise only used for probationes pennae. These repeat the text by 'hand B' and the beginning of Priamel no. 1. The hands of the probationes pennae cannot be distinguished with certainty: it is possible that it was

55 Der hund der lag jnn der ... ('The dog lay in the ...'). 
only one hand, although four different styles of writing can be distinguished ('hands $\mathrm{D}^{1}-\mathrm{D}^{4}$ ').

Today, the largest part of the title page is filled with addenda by 'hand C'. These were probably already added before those by 'hand B'. ${ }^{56}$ 'Hand C' wrote extracts from Ovid's Ars amatoria in a humanistic script. The choice of the text passages and of the captions by the writer reveals an interest in the concept of authorship..$^{57}$ A connection between this piece of humanist scholarship and the anonymous German texts of the other hands is not evident.

However, the most interesting subsequent 'entries' are deletions. These can also be understood as a kind of commentary. The person who crossed out the texts has read them and did not agree with their messages or wording. This 'editor' did not want others to read these texts. His or her aim was to prevent the further distribution of these passages. However, since a red pen was used for this purpose, reading is not physically prevented. It is only clearly marked which parts should not be read.

The deletions follow, as in many other manuscripts, two different patterns: theologically questionable and sexually explicit texts were deleted.$^{58}$ The first pattern leads to the deletion of the text that devaluates prayer on fol. $2^{\mathrm{r}}$, which had been added by 'hand E'. All other deletions follow the second pattern. This applies to the two other entries of 'hand E' on fol. $5^{\mathrm{v}}$, as well as to the texts no. 5 , 7, 8 and 12 of 'hand A'. Passages in which zers ('penis'), votze / fudt ('vagina') or minn ('sex') directly name the genitals and the sexual act are deleted. Also, those passages that use similes or metaphors to do so (no. 7, 8). Only the metaphor 'playing in the lower pocket' (no. 3) has not been deleted. It may not have been understood as a sexual innuendo or might have been overlooked.

The direct, explicit speaking about sexuality is, however, an essential feature of the Priamel genre. We encounter it in late medieval German literature as well in Märe, Minnerede, Fastnachtspiel and in many short poems (Sprüche). ${ }^{59}$

56 This is indicated by the position of the text Der hund...

57 Excerpts from Ovid, Ars amatoria, Book III, under the following headings: Famam Poëtæ appetunt ('The poets desire fame') (v. 403-414), Poëtica ars facit ad bonos mores (v. 539-542) ('The art of poetry gives good customs'), Aliud ('another') (v. 545-546), Poetæ diuino afflati spiritu.) ('Poets inspired by the divine spirit') (v.549-550). Verse numbers according to Albrecht 2003.

58 Examples are given in Heiles 2018b, Heiles 2018a, 194-203; Heiles 2014; Gerhardt 2007, 21 n. 43; Kruse 2000; Kruse 1996, 74-75.

59 Cf. Heiland 2015; Grafetstätter 2013, 35-37; Classen and Dinzelbacher 2008; Gerhardt 2007, 12-21; Erb 1998; Müller 1988. 
Research literature consistently describes this type of speaking as obscene. ${ }^{60}$ However, this prevents a real analysis and historic deconstruction of the phenomenon. As a scholarly category, the term 'obscenity' is useless. The use of the term obscene either only expresses that the scholar is disturbed by this kind of speaking, or only assumes a speaking taboo and a disturbed audience; in most cases without being able to prove that. ${ }^{61}$ The scribe of Cod. Donaueschingen A III 19 however, was obviously not disturbed by the sexually explicit language of the Priamel, nor was the buyer or the later hands ' $E$ ' and 'F', for whom particularly these texts were interesting and provoked affirmative reactions. Only at a certain point in time, the manuscript must have come to a reader who no longer appreciated the genre conventions. Remarkably, such censorship also affected the oldest known Priamel print (see Fig. 4 below). There two verses were deleted, in which the words fotzen ('vaginas'), ersen ('arses'), hoden ('testicles') and zersen ('penises') are mentioned. This phenomenon could not be explained solely by a (possible) long time distance of reception and an altered general zeitgeist, but also by a concrete alteration in the circle of recipients at a time when the genre conventions were still quite unchanged. It is possible that sexually explicit speaking and writing was only normal and possible in a certain social milieu. But the decisive factor was probably less an aspect of class or economic wealth than an aspect of gender. Our reading of the texts copied by 'Hand A' has already shown that they were written by and for men, who distinguish themselves through devaluation not only from socially marginalized groups, but also from women and clerics. In this context, the clerics who live as celibates can certainly be understood as belonging to a separate gender identity. A change of ownership to a person from one of these two groups could have been the reason for the deletions. In one of the few meta-expressions made at the beginning of the sixteenth century about the censorship of sexually explicit language, women and clerics are mentioned as the very groups of recipients for whom texts were edited in this respect. In his 1512 edition of the writings of Heinrich Seuse (1295/1297-1366), the printer Johann Otmar explains that the word Mynn, which has undergone a change of meaning from 'love' to 'sex', ${ }^{62}$ is replaced by Lieb ('love') in his edition:

60 Descriptions of Rosenplüt's texts as obscene are for example given by Williams-Krapp 2020, 60, 63 and Glier 1992b, 230-231. Minnereden with sexually explicit language and topics are regularly labelled as obscene by Klingner and Lieb 2013, vol. 1, 30, 186,1008, 1019, 1097.

61 Marcuse 1984, 55; Gerhardt 2007, 88; Fährmann 2002; Erb 1998, 403; Müller 1988, 23; Janota 1982.

62 Cf. Heiles 2018a, 200-202 with no. 701, 703; Schnell 2007. 
Nåmlich das wort ,Mynn“ vnd des geleichen, das da yetz zůdisen zeitten nit togenlich noch zymlich, sonder schampar vnnd ergerlich ist zunnennen oder zůlesen (vor auß den frawen vnnd gaistlichen rainen personen), hab ich gewendt in das wort ,Lieb', das da allen menschen, frauwen vnnd mannen vnerschrockenlich on ergernu $\beta$ zullesen ist. ${ }^{63}$

I have changed the word Mynn and suchlike, which at this time is not to be spoken or read as virtuous or decent, but as shameful and annoying (especially to women and spiritually pure persons), into the word Lieb which is readable to everybody, women and men, without fright or annoyance.

This does not mean that explicit speaking about sexuality among women or clerics was not possible or customary at all, but rather testifies to a male discourse that did not allow them to use explicit language and edited texts accordingly.

The hypothesis of the non-clerical male readership being able to speak explicitly about sexual matters should be further examined. This also raises the question of why especially the genres in which explicit speaking about sexuality is possible (Priamel, Märe, Minnerede, Fastnachtspiel) are printed so little, and whether there is a connection between these two phenomena. If we want to understand more precisely how zeitgeist, media use, genre conventions and user circles change in the transition from the late Middle Ages and Early Modern Age, between the manuscript culture of the fifteenth and the printing culture of the sixteenth century, more studies on written artefacts (manuscripts, prints and epigraphs) are still needed.

\section{References}

Achnitz, Wolfgang (2012), 'Item daz bispyl buoch genant der welt louff. Literarische Kleinformen im Angebot des Buchhändlers Diebold Lauber', in Fasbender (ed.) 2012, 223-244. Adams, Tracy and Stephen G. Nichols (2004), 'Circa 1400. The Culture of the Book', in David E. Wellerby, Judith Ryan, Hans Ulrich Gumbrecht, Anton Kaes, Joseph Leo Koerner and Dorothea E. von Mücke (eds), A New History of German Literature, Cambridge, MA: Harvard University Press, 158-164.

Albrecht, Michael von (ed.) (2003), Ovidius Naso, Ars amatoria/Liebeskunst, $2^{\text {nd }}$ edn, Stuttgart: Reclam.

Bangert, Julia (2019), Buchandelssystem und Wissensraum in der Frühen Neuzeit (Schriftmedien/ Written Media, 7), Berlin: De Gruyter.

63 Diss buch das da gedicht hat der erleücht vater Amandus genant Seüß, [...] Augsburg: Johann Otmar 1512, fol. ccxviii ${ }^{\mathrm{r}}$ [VD16 S 6097], according to the exemplar kept in Munich, Staatsbibliothek, Res/2 P. lat 1430 <daten.digitale-sammlungen.de/bsb00018923/image_359>. 
Classen, Albrecht and Peter Dinzelbacher (2008), 'Futilitates Germanicae Medii Aevi redivivae', Mediaevistik, 21: 139-157.

Dicke, Gerd (2007), 'Priamel', in Reallexikon der deutschen Literaturwissenschaft, vol. 3, Berlin: De Gruyter, 157-159.

Diefenbacher, Michael and Horst-Dieter Beyerstedt (2012), 'Nürnberg', in Wolfgang Adam and Siegrid Westphal (eds), Handbuch kultureller Zentren der Frühen Neuzeit: Städte und Residenzen im alten deutschen Sprachraum, Berlin: De Gruyter, vol. 3, 1569-1610.

Dirmeier, Ulf (1984), Zu den materiellen Lebensbedingungen in deutschen Städten des Spätmittelalters: Äußere Rahmen, Einkommen, Verbrauch, Siegen: Voigt.

Dondi, Christina (2020), 'From the Corpus luris to "psalterioli da puti”, on Parchment, Bound, Gilt... The Price of Any Book Sold in Venice 1484-1488', in Christina Dondi (ed.), Printing $R$-Evolution and Society 1450-1500. Fifty Years that Changed Europe (Studi di storia, 13), Venice: Ca’Foscari Digital Publishing, 577-600.

Erb, James R. (1998), 'Uncomfortable Metaphors: Philology, Obscenity and the Nuremberg Fastnachtspiele', Exemplaria, 10/2: 371-403

Fährmann, Sogrid (2002), 'Obszönitäten', in Enzyklopädie des Märchens. Handwörterbuch zur historischen Erzählforschung, vol. 10, Berlin: De Gruyter, 178-183.

Fasbender, Christoph (ed.) (2012), Aus der Werkstatt Diebold Laubers (Kulturtopographie des alemannischen Raums, 3), Berlin: De Gruyter.

Fischer, Hanns (1983), Studien zur deutschen Märendichtung, $2^{\text {nd }}$ edn, Tübingen: Max Niemeyer.

Gerhardt, Christoph (2007), Grobianische Diätetik. Zu den sieben größten Freuden in Rede, Lied und Priamel sowie zu dem Fachstnachtspiel 'Das Ungetüm' (Kleine Reihe. Literatur Kultur - Sprache, 3), Trier: Wissenschaftlicher Verlag.

Glier, Ingeborg (1992a), 'Rosenplüt, Hans', in Die deutsche Literatur des Mittelalters. Verfasserlexikon, $2^{\text {nd }}$ edn, vol. 8, Berlin: De Gruyter, 195-211.

Glier, Ingeborg (1992b), 'Rosenplütsche Fastnachtspiele', in Die deutsche Literatur des Mittelalters. Verfasserlexikon, $2^{\text {nd }}$ edn, vol. 8, Berlin: De Gruyter, 211-232.

Grafetstätter, Andrea (2013), Ludus compleatur. Theatralisierungsstrategien epischer Stoffe im spätmittelalterlichen und frühneuzeitlichen Spiel (Imagines medii aevi, 33), Wiesbaden: Reichert.

Griese, Sabine (2000), 'Gebrauchsformen und Gebrauchsräume von Einblattdrucken des 15. und frühen 16. Jahrhunderts', in Volker Honemann, Sabine Griese, Falk Eisermann and Marcus Osterhammel (eds), Einblattdrucke des 15. und frühen 16. Jahrhunderts. Probleme, Perspektiven, Fallstudien, Tübingen: Max Niemeyer, 179-208.

Griese, Sabine (2019), 'Rosenplüt im Kontext', in Seraina Plotke and Stefan Seeber (eds), Schwanksammlungen im frühneuzeitlichen Medienumbruch. Transformationen eines sequentiellen Erzählparadigmas (Germanisch-Romanische Monatsschrift. Beiheft, 96), Heidelberg: Winter, 61-90.

Heiland, Satu (2015), Visualisierung und Rhetorisierung von Geschlecht. Strategien zur Inszenierung weiblicher Sexualität im Märe, Berlin: De Gruyter.

Heiles, Marco (2010), ‘Topography of German Humanism 1470-1550. An Approach’, published on Humanities Commons <dx.doi.org/10.17613/ktg9-nm81>.

Heiles, Marco (2014), 'Salvation of the soul and prudery. Censoring a 15th-century Germanlanguage manuscript', Manuscript of the Month, $12<\mathrm{http}$ :/ www.manuscript-cultures.unihamburg.de/mom/2014_12_mom_e.html> (accessed on 16 Feb. 2021). 
Heiles, Marco (2018a), Das Losbuch. Manuskriptologie einer Textsorte des 14. bis 16. Jahrhunderts (Beihefte zum Archiv für Kulturgeschichte, 83), Wien: Böhlau.

Heiles, Marco (2018b), 'Scham und Obszönität in mittelalterlichen deutschen Handschriften. Probleme und Perspektiven' [paper given in Berlin on 07 Feb. 2018], published on Humanities Commons <dx.doi.org/10.17613/M6ZP3W04J).

Heiles, Marco (forthcoming), 'Literarische Texte in der Sammelhandschrift des Heidelberger Studenten Conrad Buitzruss aus dem Jahre 1424 (München, Staatbibliothek, Clm 671)', in Philippe Depreux and Till Hennings (eds), Collection and Organisation of Literary Texts in Early Medieval Manuscripts (Hamburger Studien zu Gesellschaft und Kulturen der Vormoderne), Stuttgart: Franz Steiner.

Herz, Randall (2008), 'Das Titelblatt in Nürnberg: Entwicklungslinien der Titelformulierung und Titelblattgestaltung', Archiv für Geschichte des Buchwesens, 63: 43-92.

Hohenbühel-Heufler, Ludwig Ritter von (1883), 'Alte Priameln in Mils', Germania, 28: 417-420. Horváth, Eva und Hans-Walter Stork (eds.) (2002), Von Rittern, Bürgern und von Gottes Wort. Volkssprachige Literatur in Handschriften und Drucken aus dem Besitz der Staats- und Universitätsbibliothek Hamburg (Schriften aus dem Antiquariat Dr. Jörn Günther, Hamburg, 2), Kiel: Ludwig [available as online edition on <handschriftencensus.de/ forschungsliteratur/pdf/910> (accessed on 16 Feb.)].

Huey, Caroline (2012), Hans Folz and Print Culture in Late Medieval Germany. The Creation of Popular Discourse, Farnham: Ashgate.

Janota, Johannes (1982), 'Schmutzfinken oder Rebellen? Probleme der Forschung mit dem Obszönen in den mittelalterlichen Fastnachtspielen', Siegener Hochschulblätter, 5/2: 5670.

Keller, Adelbert von (1853), 'Fastnachtsspiele aus dem fünfzehnten Jahrhundert', vol. 1, Stuttgart: Litterarischer Verein.

Kiepe, Hansjürgen (1984), Die Nürnberger Priameldichtung. Untersuchungen zu Hans Rosenplüt und zum Druck- und Schreibwesen im 15. Jahrhundert (Münchener Texte und Untersuchungen zur deutschen Literatur des Mittelalters, 74), Munich: Artemis.

Klingner, Jakob (2010), Minnereden im Druck. Studien zur Gattungsgeschichte im Zeitalter des Medienwechsels (Philologische Studien und Quellen, 226), Berlin: Erich Schmidt.

Klingner, Jakob and Ludger Lieb (2013), Handbuch Minnereden, 2 vols, Berlin: De Gruyter.

Kremer, Richard (2003), 'Hans Sporer's Xylographic Practices. A Census of Regiomontanus's Blockbook Calendar', in Bettina Wagner (ed.), Blockbücher des 15. Jahrhunderts. Eine Experimentierphase im frühen Buchdruck. Beiträge der Fachtagung in der Bayerischen Staatsbibliothek München am 16. und 17. Februar 2012 (Bibliothek und Wissenschaft, 46), Wiesbaden: Harrassowitz, 161-188.

Kruse, Britta-Juliane (1996), Verborgene Heilkünste: Geschichte der Frauenmedizin im Spätmittelalter (Quellen und Forschungen zur Literatur- und Kulturgeschichte, 44), Berlin: De Gruyter.

Kruse, Britta-Juliane (2000), 'Zensierter Zauber: Getilgte magische und mantische Texte in einer Berliner Handschrift', in Peter Jörg Becker (ed.), Scrinium Berolinense. Tilo Brandis zum 65. Geburtstag (Beiträge aus der Staatsbibliothek zu Berlin - Preußischer Kulturbesitz, 10), Wiesbaden: Reichert, vol. 1, 383-397.

Marcuse, Ludwig (1984), Obszön. Geschichte einer Entrüstung, Zürich: Diogenes [1 $1^{\text {st }}$ edn: 1962]. 
Müller, Johannes (1988), Schwert und Scheide. Der sexuelle und skatologische Wortschatz im Nürnberger Fastnachtspiel des 15. Jahrhunderts (Deutsche Literatur von den Anfängen bis 1700, 2), Bern: Peter Lang.

Neddermeyer, Uwe (1996), 'Möglichkeiten und Grenzen einer quantitativen Bestimmung der Buchproduktion im Spätmittelalter', Gazette du livre médiéval, 28: 23-32.

Neddermeyer, Uwe (1998), Von der Handschrift zum gedruckten Buch. Schriftlichkeit und Leseinteresse im Mittelalter und in der frühen Neuzeit. Quantitative und qualitative Aspekte (Buchwissenschaftliche Beiträge aus dem Deutschen Bucharchiv München, 61), 2 vols, Munich: Harrasowitz.

Needham, Paul (1994), 'Res Papirae: Sizes and Formats of the Late Medieval Book', in Peter Rück (ed.), Rationalisierung der Buchherstellung im Mittelalter und in der Frühen Neuzeit: Ergebnisse eines Buchgeschichtlichen Seminars, Wolfenbüttel 12.-14. November 1990, Marburg: Institut für Historische Hilfswissenschaften.

Needham, Paul (2017), 'Format and Paper Size in Fifteenth-century Printing', in Christoph Reske and Wolfgang Schmitz (eds), Materielle Aspekte in der Inkunabelforschung (Wolfenbütteler Schriften zur Geschichte des Buchwesens, 49), Wiesbaden: Harrassowitz, 59108.

Ott, Norbert H. (2010), 'Spaun, Claus', in Neue Deutsche Biographie 24, 633-634 <deutschebiographie.de/pnd119522608.html\#ndbcontent> (accessed on 16 Feb. 2021).

Pfister, Silvia (1986), 'Sind Priameln "Bildgedichte”? Hinweis auf einen unbekannten PriamelEinblattdruck', Zeitschrift für deutsches Altertum und deutsche Literatur, 115: 228-233.

Rautenberg, Ursula (1999), 'Das Werk als Ware: Der Nürnberger Kleindrucker Hans Folz', Internationales Archiv für Sozialgeschichte der deutschen Literatur, 24: 1-40.

Rautenberg, Ursula (2004), Das Titelblatt. Die Entstehung eines typographischen Dispositivs im frühen Buchdruck (Alles Buch. Studien der Erlanger Buchwissenschaft, 10), Erlangen: Buchwissenschaft.

Rautenberg, Ursula (2008), 'Die Entstehung und Entwicklung des Buchtitelblatts in der Inkunabelzeit in Deutschland, den Niederlanden und Venedig - Quantitative und qualitative Studien', Archiv für Geschichte des Buchwesens, 62: 1-105.

Sauer, Christine (2017), 'Anton Koberger und seine “Manufaktur” - (k)ein Forschungsthema?', Wolfenbütteler Notizen zur Buchgeschichte, 42: 77-96.

Schmitz, Wolfgang (2018), Grundriss der Inkunabelkunde. Das gedruckte Buch im Zeitalter des Medienwechsels (Bibliothek des Buchwesens, 27), Stuttgart: Hiersemann.

Schnell, Rüdiger (2007), 'Sprachhistorische Einsichten und editorische Entscheidungen. Überlegungen zur deutschen Übersetzung der Regula Benedicti', in Michael Stolz (ed.), Edition und Sprachgeschichte. Baseler Fachtagung 2.-4. März 2005 (Editio. Beihefte, 26), Tübingen: Niemeyer, 117-140.

Schreiber, Wilhelm Ludwig (1927), Handbuch der Holz- und Metallschnitte des XV. Jahrhunderts, vol. 4, Leipzig: Hiersemann.

Schreiber, Wilhelm Ludwig (1928), Handbuch der Holz- und Metallschnitte des XV. Jahrhunderts, vol. 6, Leipzig: Hiersemann.

Schwob, Anton (ed.) (2004), Die Lebenszeugnisse Oswalds von Wolkenstein. Edition und Kommentar, vol. 3, Wien: Böhlau.

Simon, Eckehard (2004), 'Circa 1450. Fastnachtsspiele', in David E. Wellerby, Judith Ryan, Hans Ulrich Gumbrecht, Anton Kaes, Joseph Leo Koerner and Dorothea E. von Mücke (eds), $A$ New History of German Literature, Cambridge, MA: Harvard University Press, 178-183. 
Simon, Gerd (1970), Die erste deutsche Fastnachtsspieltradition. Zur Überlieferung, Textkritik und Chronologie der Nürnberger Fastnachtsspiele des 15. Jahrhunderts (Germanische Studien, 240), Lübeck: Matthiesen.

Trovato, Paolo (2014), Everything You Always Wanted to Know about Lachmann's Method: A Non-Standard Handbook of Genealogical Textual Criticism in the Age of PostStructuralism, Cladistics, and Copy-Text, Firenze: Libreriauniversitaria.it edizioni.

Williams-Krapp, Werner (2020), Die Literatur des 15. und frühen 16. Jahrhunderts, vol. 1: Modelle literarischer Interessensbildung (Geschichte der deutschen Literatur von den Anfängen bis zum Beginn der Neuzeit, 3.2.1), Berlin: De Gruyter.

Wimmer, Hanna, Dmitry Bondarev, Janina Karolewski and Vito Lorusso, $A$ heuristic tool for the comparative study of manuscripts from different manuscript cultures (CSMC - Occasional Paper No. 3), Hamburg 2015 <https://www.manuscript-cultures.uni-hamburg.de/papers/ CSMC_Occasional_Paper_3_Wimmer_et_al.pdf> (accessed on 6. Apr. 2021). 


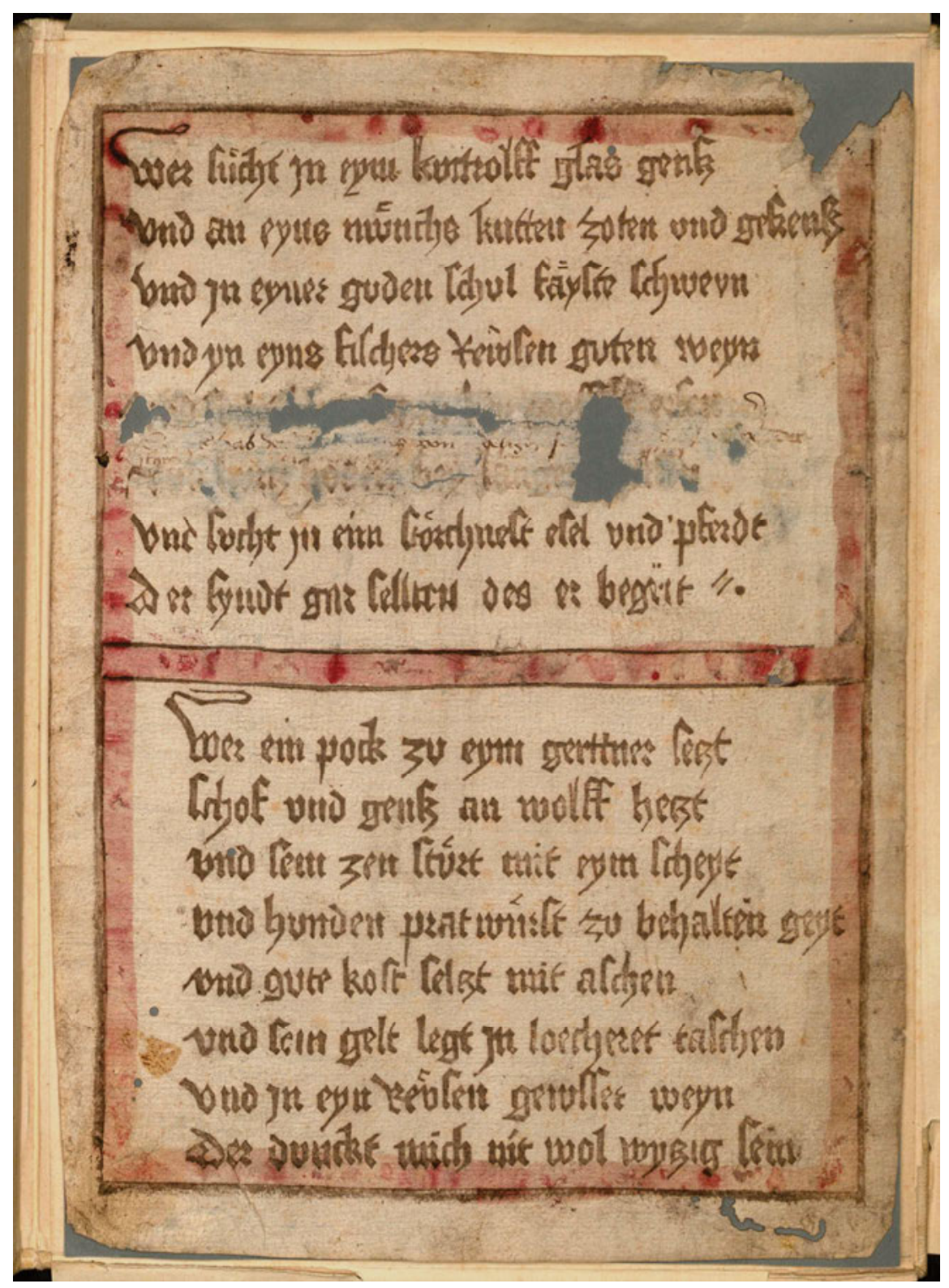

Fig. 4: Xylographic Print of two Priamel. Nuremberg?, c. 1460-1470. Munich, Bayerische Staatsbibliothek, Xylogr. 88. CC BY-NC-SA (courtesy of Bayerische Staatsbibliothek). 


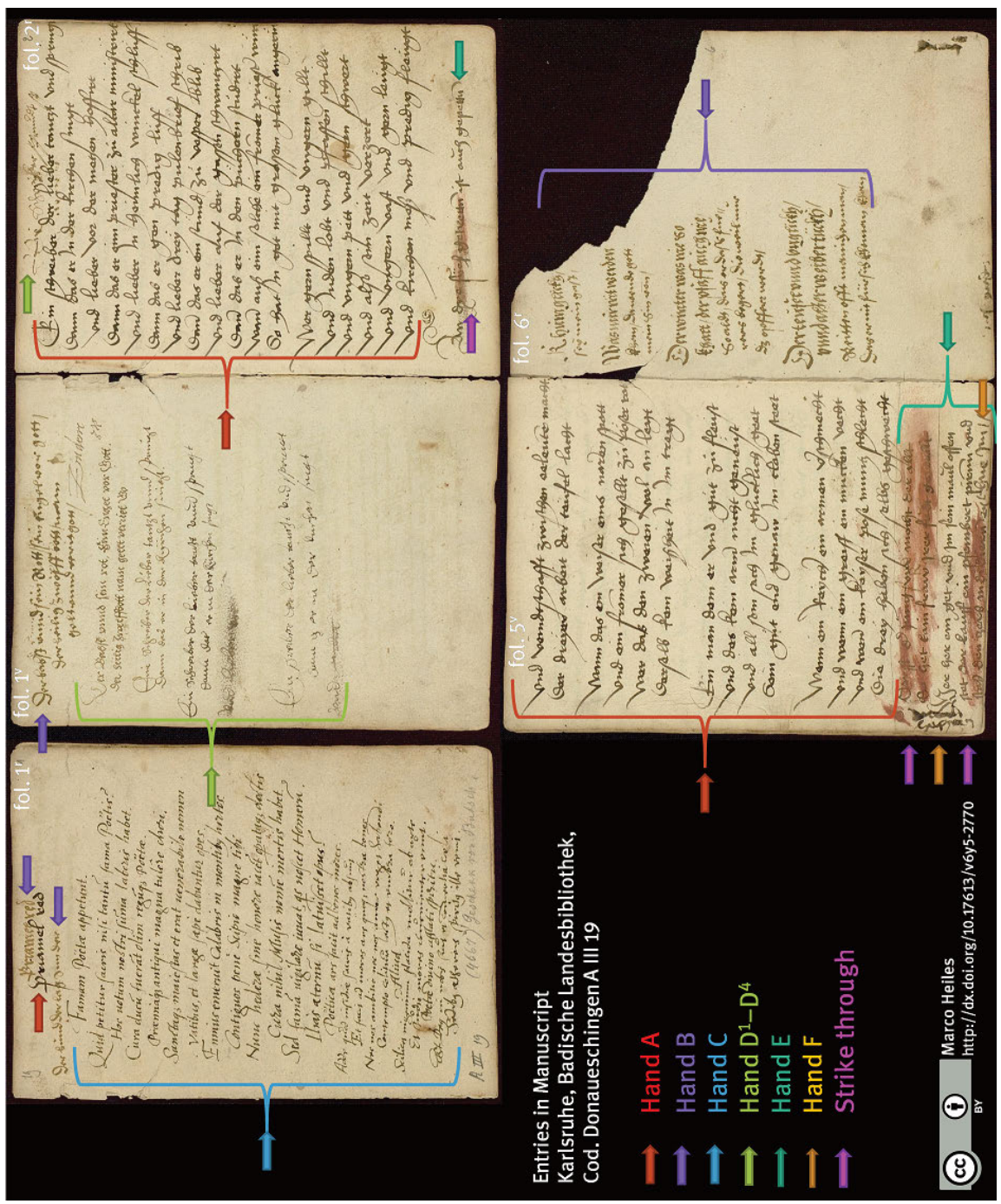

Fig. 5: Entries in Cod. Donaueschingen A III 19. Images of the manuscript by the Badische Landesbibliothek Karlsruhe: 〈https://nbn-resolving.de/urn:nbn:de:bsz:31-37635> (CC BY 4.0). Online version of this image: <http://dx.doi.org/10.17613/v6y5-2770>. 
